\title{
Stability of Economic Growth Rates in Jordan: Measurement and Analysis
}

\author{
Yaseen Altarawneh, Saeed Mahmoud, Alaaeddin Al-Tarawneh \\ Business Economics Department, School of Business, University of Jordan, Amman, Jordan \\ Email address: \\ y.tarawneh@ju.edu.jo (Y. Altarawneh), s.tarawneh@ju.edu.jo (S. Mahmoud), a.alTarawneh@ju.edu.jo (A. Al-Tarawneh)
}

\section{To cite this article:}

Yaseen Altarawneh, Saeed Mahmoud, Alaaeddin Al-Tarawneh. Stability of Economic Growth Rates in Jordan: Measurement and Analysis. International Journal of Business and Economics Research. Vol. 9, No. 3, 2020, pp. 125-129. doi: 10.11648/j.ijber.20200903.15

Received: April 1, 2020; Accepted: April 20, 2020; Published: May 14, 2020

\begin{abstract}
Jordan's economy faces several difficulties and challenges. These challenges and difficulties are represented by the small size of the economy on the one hand and the scarcity of its financial and natural resources on the other. These two problems and others have forced the Jordanian economy to be dependent on the outside in several areas. Which in turn made the economy easily exposed to external shocks, whether economic or political. So that this study was mainly aimed at demonstrating the extent to which the Jordanian economy has been affected by external events. To achieve this goal, data were used for the period 1976-2018. Two approaches were applied, one descriptive while the second is econometrics. Stability has been measured and analyzed for long and short periods in three dimensions: GDP growth rates, value-added growth rates by sectors: agricultural, mining, industrial, construction, and services. Growth rates for aggregate demand components: private consumption, government spending, investment, exports, and imports. The results indicated the ability of the Jordanian economy to adapt and absorb shocks from abroad, and the results also showed that instability increases as the economy faces external crises. Finally, the results showed that the stability of GDP growth is linked to the stability of the services sector.
\end{abstract}

Keywords: Economic Growth, Economic Growth Stability, Macroeconomic Stability, Jordan Economy, External Shock

\section{Introduction}

Jordan's economy has grown rapidly, with GDP increasing from 567.3 million JD in 1976 to 29948.2 million JD in 2018 with an average growth rate of about $5 \%$ per annum. This achievement was accomplished despite the difficulties and challenges faced by the Jordanian economy, these challenges are represented by the small size of the economy on the one hand and the scarcity of its financial and natural resources on the other hand.

These two problems and others have forced the Jordanian economy to be dependent on the outside in several areas. As a result of the scarcity of resources, the production base is narrow, which in turn forced the economy to import most of its needs, imports increased from 12 to 20 for the years 1976, 2018 respectively, and imports grew by 4\%. Also the small size of the market and the low level of purchasing power urged the economy to look for markets for its traditional products of agricultural materials, nowadays Jordan faces problems in exporting its products to neighboring Arab markets due to political instability: Iraq,
Syria, and Lebanon.

The scarcity of domestic financial resources enforced the economy to look for external sources of financing, these sources were the assistance of Arab oil countries and developed countries such as America and the European Union, as well as borrowing from abroad.

Another source of external dependency of Jordanian economy is the dependence of the balance of foreign reserves on the remittances of workers as an important source. The Gulf Arab states absorb large numbers of workers from Jordan, this worker is forced to return to Jordan depending on the circumstances and political events, in 1991 about 500 thousand workers and their families returned to Jordan because of his view of the invasion of Kuwait.

The above facts about the Jordanian economy show that the economy is easily exposed to external shocks, whether economic or political.

This study aims to measure and analyze economic stability in Jordan at three levels: GDP, sector level (agricultural, mining, industrial, construction, services), and components of aggregate demand (private consumption, government 
spending, investment, exports, and imports).

\section{Literature Review}

Achievement of stable economy through steady GDP growth, maintain low level of both unemployment and inflation is a main goal for any society. The importance of this stability arises from the harmful sequences of wide fluctuation in GDP as a key measure variable of economic condition, instability through many mechanism negatively affect the economy: it creates uncertainty which in turn reduce incentives for private investment, offer reason for capital flight, creates unstable social aspects of society, and unstable political system.

Many studies had been conducted to calculate macroeconomic instability index and estimate its effect on growth and other variables. For the period 1970-1999, a strong relation between growth and macroeconomic stability was found by Sirimaneetham \& Temple for a sample of 70 developing countries [1]. Also negative effect for macroeconomic instability on growth found by Ramey \& Ramey in there study for 92 economies for $1960-1988$ period and 24 OECD economies for a period of 1950-1988 [2]. Liew \& others showed that macroeconomic instability has negative impact on economic performance as peroxided by GDP per capita in Malaysia for 1984-2016 period [3].

Using nonlinear ARDL method and quarterly data: 1998Q2-2014Q4 Gulay examines the effect of macroeconomic instability on growth for Turkey. He concludes that increasing macro instability indicates a negative business climate, therefore harmful economic growth [4]. Similar results obtained by Haghighi \& others for Iran [5]. They implemented neoclassical endogenous growth model using time series data from 1974 to 2008 . The results showed long term relationship between macro instability and economic growth.

Other studies analyze the impact of macro instability on investment. Ahangari \& Saki implements ECM technique for Iran for 1963-2003, their results showed negative impact for macro instability on private investment [6]. Same result obtained for Nigeria by Olaniyan [7]. Shamshir \& others investigate the impact of macro stability on foreign direct investment (FDI) in Pakistan [8]. The result for the 19752015 period showed positive effect for macro stability on FDI.

Somoye \& Bamidele approved a long - run relationship between macro instability and banking sector lending behavior in Nigeria, they used Co-integration and Vector error correction models for time series spanned 1986-2005 [9]. Similarly, Talavera $\&$ others found negative relationship between macroeconomic uncertainty and bank lending in Ukraine [10]. Also, Baum \& others analyze the impact of macroeconomic uncertainty on the behavior of US banks using quarterly data from 1979- 2003, Q3. They found that bank loans response negatively to macroeconomic instability [11].

Yaprakl 1 \& others analyze the impacts of macroeconomic stability among other variables on economic growth in 48 middle income countries, for 2002-2011 period [12]. They found macroeconomic stability affect economic growth in a positive way. They also found low level of contribution for macroeconomic stability on economic growth in these countries. Same result obtained by Tatiana \& others for Ukraine for 200-2016 period [13]. They found positive and significant effect for macroeconomic stability on economic growth. Other studies have indicated that the application of both fiscal and monetary policies is more effective in achieving economic stability than the application of a single policy. (see for example [14, 15], and [16]).

\section{Methodology.}

Data for the 1976-2018 period were used to measure and analyze the stability of Jordan's economic growth rates. Two methods have been used to achieve this goal. The following formula was applied in the first method

$$
\mathrm{S}=\frac{x-\min X}{\max X-\min X}
$$

Where: $\mathrm{X}$ value in time $\mathrm{t}$

Min X, the lowest value of the variable in target period

Max X, the maximum value of the variable in target period

The second approach was based on the estimation of the following equation:

$$
\mathrm{X}_{\mathrm{t}}=\alpha \mathrm{D}+\beta \mathrm{X}_{\mathrm{t}}+\sum^{\mathrm{p}} \mathrm{j}=1 \theta \Delta \mathrm{X}_{\mathrm{t}}+\mathrm{e}_{\mathrm{t}}
$$

Where $\mathrm{D}$ : constant and trend, $\mathrm{x}$ : targeted variable, $\mathrm{p}$ number of lags, e: error term.

$\alpha, \beta, \theta$ the parameters

The parameter $\beta$ significance was tested to indicate stability through Dickey-Fuller test of stationary.

Unlike previous studies, to study the sources and roots of instability the two models will be applied to GDP growth rates, value-added growth rates by sectors, as well as growth rates in aggregate demand components.

The first model will be implemented for 1976-2018 and for five partial periods

While the second model will be applied for periods 19762016, 1976-1996 and 1997-2016.

\section{Estimation and Analysis}

To measure the stability of GDP as well as value added by sectors, the formula 1 was applied (table 1). The results for the period 1976-2018 indicated that the GDP stability index ranged between 0 and 0.99 and averaged 0.3 , and it did not differ by sector, with the index ranging from 0 to 1 per sector and averages were close to average GDP excluding the agricultural sector. The stability index was about 0.25 for both the services and mining sectors, and 0.33 for the construction and industry sector, while agriculture was 0.45 . As for the volatility of the stability index as expressed in the coefficient of variation, the results showed that the highest volatility rate was in GDP and the services sector at 0.86 , 
while in agriculture and construction it was 0.5 and about 0.6 in mining and industry.

Table 1. Average stability index and coefficient of variation for GDP and Sectors.

\begin{tabular}{|c|c|c|c|c|c|c|c|}
\hline & & Agricultural & Mineral & manufacturing & Consumption & Service & GDP \\
\hline \multirow{2}{*}{ 1976-2018 } & AV & 0.46 & 0.25 & 0.34 & 0.33 & 0.24 & 0.30 \\
\hline & C.V & 0.52 & 0.66 & 0.6 & 0.55 & 0.86 & 0.86 \\
\hline \multirow{2}{*}{ 1976-1985 } & AV & 0.52 & 0.41 & 0.41 & 0.71 & 0.36 & 0.41 \\
\hline & C.V & 0.79 & 1.03 & 1.02 & 0.57 & 1.19 & 0.84 \\
\hline \multirow{2}{*}{ 1986-1995 } & AV & 0.41 & 0.18 & 0.46 & 0.26 & 0.45 & 0.36 \\
\hline & C.V & 0.96 & 2.61 & 0.91 & 1.69 & 0.94 & 1.2 \\
\hline 1996-2005 & $\mathrm{AV}$ & 0.58 & 0.41 & 0.53 & 0.51 & 0.39 & 0.4 \\
\hline \multirow{2}{*}{ 2006-2018 } & AV & 0.31 & 0.24 & 0.37 & 0.35 & 0.27 & 0.27 \\
\hline & C.V & 0.54 & 0.94 & 1.1 & 0.88 & 0.94 & 0.98 \\
\hline
\end{tabular}

The length of the 42-year time period makes it difficult to obtain stable indicators, so the total period has been divided into four partial periods: 1976-85, 1986-95, 1996-2005, 2006-2018.

For the first period, the GDP stability index was about 0.5 , and it recorded a clear fluctuation during the period rising and falling again, with a difference factor of 0.84 . At the sector level, the services sector recorded the lowest value of 0.36 while the maximum value was 0.71 in the construction sector, and the index was the most volatile in the services sector 1.19 and the lowest in construction 0.57

In the second period 1986-95, the results indicated that the average stability index for GDP, agriculture and services sector were about $(0.4)$, while the index was high in the industrial sector 0.64 and low in the mining sector 0.18 and the construction sector 0.26 ,

The volatility factor indicated that the level of volatility in the index of GDP, services, agriculture and industry was close around 0.9 , while the highest volatility in the mining sector was 2.61 and the construction sector was 1.69.

In 1996-2005, the results showed that the average stability index (0.4) as well as the level of volatility (1.1) was almost equal for GDP, the mining sector and the services sector, while the average index was approximately 0.5 and the level of volatility was 0.7 in the rest of the sectors.

In the most recent period, 2006-2018, stability indicators and volatility rates were similar for GDP, services and mining sector, average stability index recorded 0.27 and the coefficient of variation was 0.95 , the rest of the sectors recorded varying values for average stability index and oscillation coefficient.

In general, we note that the stability index as well as the volatility of GDP is linked to those in the services sector. This can be explained by the fact that the bulk of GDP comes from the services sector. It is also noted that the level of volatility was the largest in the period 1986-1995, during which the Jordanian economy witnessed many events: the devaluation of the dinar exchange rate, the invasion of Kuwait and the return of thousands of workers from the Gulf States.

Table 2 Shows the results of the estimate of the average stability index and its volatility rates for the components of total demand, the results indicate that the stability index for private consumption is about 0.5 for all periods and the coefficient of difference 0.6 excludes the period 1986-1995 where the average index decreased to 0.28 and the coefficient of difference increased To 1.2, the Investment Stability Index recorded a clear decline during periods from 0.48 for 197685 to 0.29 for 2006-2016, and the results indicated that investment ranked first in terms of the level of volatility.

Government spending ranked second in terms of volatility, the lowest value recorded 0.85 for the period 1996-2005, the highest value of 1.1 recorded in 1976-85, while the average stability index was fluctuating between periods ranging from 0.22 to 0.97

Table 2. Average stability index and coefficient of variation for aggregate demand component.

\begin{tabular}{|c|c|c|c|c|c|c|}
\hline & & $\mathrm{C}$ & G & I & $\mathbf{X}$ & M \\
\hline \multirow{2}{*}{ 1976-2018 } & AV & 0.53 & 0.22 & 0.42 & 0.53 & 0.47 \\
\hline & C.V & 0.54 & 0.97 & 0.54 & 0.45 & 0.46 \\
\hline \multirow{2}{*}{ 1976-1985 } & AV & 0.57 & 0.33 & 0.48 & 0.54 & 0.43 \\
\hline & C.V & 0.62 & 1.1 & 0.67 & 0.59 & 0.72 \\
\hline \multirow{2}{*}{ 1986-1995 } & AV & 0.28 & 0.59 & 0.38 & 0.59 & 0.52 \\
\hline & C.V & 1.2 & 0.4 & 0.76 & 0.47 & 0.51 \\
\hline 1996-2005 & AV & 0.52 & 0.44 & 0.34 & 0.37 & 0.36 \\
\hline \multirow{2}{*}{ 2006-2018 } & AV & 0.5 & 0.34 & 0.29 & 0.41 & 0.56 \\
\hline & C.V & 0.61 & 0.97 & 1.1 & 0.67 & 0.54 \\
\hline
\end{tabular}

In general, for exports and imports, the results of the average stability index and the level of volatility show a great convergence.

For example, the average stability index was 0.53 for exports and 0.47 for imports in 1976-2018 and the difference factor was 0.45 for both.

Also, in 1996-2005 the average index was 0.36 and the level of volatility was 0.88 for both export and import, 
Tables 3 and 4 summarize the results of the estimate of equation 2 in the second model. The results indicate that GDP growth rates were not stable in 1976-2018 as well as 1997-2018. This instability was accompanied by instability in the value-added growth rates of the services and construction sectors in the period 1976-2018.

Also in 1997-2018, the growth rates of value added in the above sectors were unstable as well as in the industrial sector. In 1976-1996, GDP growth rates were stable, as opposed to the service sector and the construction sector. Value-added growth rates in the agricultural and mining sectors were stable in the three periods. For the components of aggregate demand, their growth rates were stable for all periods.

Table 3. Unit Root Test Results for GDP and Sectors (ADF).

\begin{tabular}{|c|c|c|c|c|c|c|c|}
\hline & & AGR & MAN & IND & CONS & SER & GDP \\
\hline $1976-2018$ & $\begin{array}{l}\text { t-Statistic } \\
\text { Prob. }\end{array}$ & $\begin{array}{l}-6.0075 \\
0.0001 \\
* * *\end{array}$ & $\begin{array}{l}-7.1668 \\
0.0000 \\
* * *\end{array}$ & $\begin{array}{l}-6.8154 \\
0.0000 \\
* * *\end{array}$ & $\begin{array}{l}-3.0958 \\
0.1205\end{array}$ & $\begin{array}{l}-2.7507 \\
0.2230\end{array}$ & $\begin{array}{l}-2.6657 \\
0.2554\end{array}$ \\
\hline 1976-1996 & $\begin{array}{l}\text { t-Statistic } \\
\text { Prob. }\end{array}$ & $\begin{array}{l}-5.7949 \\
0.0007 \\
* * *\end{array}$ & $\begin{array}{l}-4.9102 \\
0.0041 \\
* * *\end{array}$ & $\begin{array}{l}-5.5369 \\
0.0011 \\
* * *\end{array}$ & $\begin{array}{l}-2.1523 \\
0.4895 \\
*\end{array}$ & $\begin{array}{l}-2.0182 \\
0.5569\end{array}$ & $\begin{array}{l}-3.5909 \\
0.0553\end{array}$ \\
\hline $1997-2018$ & $\begin{array}{l}\text { t-Statistic } \\
\text { Prob. }\end{array}$ & $\begin{array}{l}-3.5005 \\
0.0681 \\
*\end{array}$ & $\begin{array}{l}-4.7704 \\
0.0058 \\
* * *\end{array}$ & $\begin{array}{l}-2.9467 \\
0.1700\end{array}$ & $\begin{array}{l}-2.6200 \\
0.2759\end{array}$ & $\begin{array}{l}-1.3061 \\
0.8546\end{array}$ & $\begin{array}{l}-1.3337 \\
0.8469\end{array}$ \\
\hline
\end{tabular}

Notes:

a: $(*)$ Significant at the $10 \% ;(* *)$ Significant at the $5 \% ;(* * *)$ Significant at the $1 \%$ and (no) Not Significant

b: Lag Length based on SIC

c: Probability based on MacKinnon (1996) one-sided p-values.

Table 4. Unit Root Test Results for Aggregate demand component (ADF).

\begin{tabular}{|c|c|c|c|c|c|c|}
\hline & & C & G & I & $\mathbf{X}$ & M \\
\hline $1976-2016$ & $\begin{array}{l}\text { t-Statistic } \\
\text { Prob. }\end{array}$ & $\begin{array}{l}-5.5324 \\
0.0003 \\
* * *\end{array}$ & $\begin{array}{l}-6.6550 \\
0.0000 \\
* * *\end{array}$ & $\begin{array}{l}-5.6711 \\
0.0002 \\
* * *\end{array}$ & $\begin{array}{l}-4.7750 \\
0.0023 \\
* * *\end{array}$ & $\begin{array}{l}-5.1485 \\
0.0008 \\
* * *\end{array}$ \\
\hline 1976-1996 & $\begin{array}{l}\text { t-Statistic } \\
\text { Prob. }\end{array}$ & $\begin{array}{l}-11.3456 \\
0.0000 \\
* * *\end{array}$ & $\begin{array}{l}-12.7496 \\
0.0000 \\
* * *\end{array}$ & $\begin{array}{l}-6.9706 \\
0.0000 \\
* * *\end{array}$ & $\begin{array}{l}-8.9560 \\
0.0000 \\
* * *\end{array}$ & $\begin{array}{l}-6.8254 \\
0.0000 \\
* * *\end{array}$ \\
\hline $1997-2016$ & $\begin{array}{l}\text { t-Statistic } \\
\text { Prob. }\end{array}$ & $\begin{array}{l}-11.6276 \\
0.0000 \\
* * *\end{array}$ & $\begin{array}{l}-12.5146 \\
0.0000 \\
* * *\end{array}$ & $\begin{array}{l}-7.1689 \\
0.0000 \\
* * *\end{array}$ & $\begin{array}{l}-9.1777 \\
0.0000 \\
* * *\end{array}$ & $\begin{array}{l}-6.9679 \\
0.0000 \\
* * *\end{array}$ \\
\hline
\end{tabular}

Notes:

a: $(*)$ Significant at the $10 \% ;(* *)$ Significant at the $5 \% ;(* *)$ Significant at the $1 \%$ and (no) Not Significant

b: Lag Length based on SIC

c: Probability based on MacKinnon (1996) one-sided p-values.

\section{Conclusion}

Despite the heavy dependence of the Jordanian economy on the outside in several areas, this could make it vulnerable to external shocks, politically or economically. However, GDP as well as sector-level economic growth rates have been fairly stable in long and short periods. This shows the ability of the Jordanian economy to adapt and absorb shocks.

\section{References}

[1] Sirimaneetham, v., \& Temple, w., (2009). Macroeconomic stability and the distribution of growth rate. The World Bank Economic Review, 23 (3), 443-479.

[2] Ramey, G., \& Ramey, V. A. (1995). Cross-Country Evidence on the Link Between Volatility and Growth. The American Economic Review, 85 (5), 1138-1151.

[3] Liew, Venus Khim-Sen, Racquel Anak Rowland, Puah Chin Hong, Jerome Kueh Swee Hui, Rossazana Bt Ab Rahim, Shirly Wong Siew Ling. (2018). Macroeconomic Instability
Index and Malaysia Economic Performance. International Business Research, 11 (3), 179-185.

[4] Gulay, Emrah. (2019). The nexus prevalent in nonlinear finance and growth in the presence of macroeconomic instability in turkey: Does the stock market really matter? Business and Economic Horizons, 15 (1), 1-19.

[5] Haghighi, Karnameh., Majid Sameti \& Rahim Dallali Isfahani (2012). The Effect of Macroeconomic Instability on Economic Growth in Iran. Research in Applied Economics, 4 (3), 39-61.

[6] Ahangari, Abdolmajid., and Aziz Saki. (2012). A study on the effect of macroeconomics instability index on private investment in Iran. Management Science Letters, 2, 1939 1946.

[7] Olaniyan O. (2000) The Effects of Instability on Aggregate Investment in Nigeria. The Nigerian Journal of Social and Economic Studies, 42 (1), 23-26.

[8] Shamshir, Musarrat. Samina Sabir, and dr. rukhsana khan. (2019). Impact of Macroeconomic Stability and Terrorism on Foreign Direct Investment in Pakistan. New Horizons, 13 (2), 223-240. 
[9] Somoye, Russell Olukayode Christopher, and Bamidele Ilo M. (2009). The Impact of Macroeconomic Instability on the Banking Sector Lending Behaviour in Nigeria. Journal of Money, Investment and Banking, Issue 7, 88-100.

[10] Talavera Oleksandr; Tsapin Andry; Zholud Oleksandr (2006) Macroeconomic uncertainty and Bank Lending: The Case of Ukraine. German Institute for Economic Research Discussion Paper Series 637. November pp. 1-24.

[11] Baum, Christopher F, Mustafa Caglayan and NeslihanOzkan (2005) The Second Moment Matter: The Response of Bank Lending Behaviour to Macroeconomic Uncertainty. www.gla.ac.uk/media/media_22217_en.pdf

[12] Yapraklı, Sevda, Kaplan, Fatih and Yavuz, Nilgün Çil (2014), The Impacts Of Institutions, Openness And Macroeconomic Stability On Economic Growth: A Panel Data Analysis On Middle Income Countries, Journal of Econometrics and Statistics. 18 (20), 104-123.
[13] Tatiana Vasylieva, Sergij Lyeonov, Oleksii Lyulyov and Kostiantyn Kyrychenko (2018) Macroeconomic Stability and Its Impact on the Economic Growth of the Country, Montenegrin Journal of Economics, Vol 14, Iss 1, 159-170.

[14] Hagen, J. V. and Mundschenk, S. (2003), Fiscal and Monetary Policy Coordination in EMU, International Journal of Finance and Economics, Vol. 8, 279-295.

[15] Qingwang, G., Junxue, J., Yongjie, Z. and Zhiyun, Z. (2011), Mix of Fiscal and Monetary Policy Rules and Inflation Dynamics in China, China \& World Economy, Vol. 19, 47-66.

[16] Agus Arifin, F. X. Sugiyanto, Wahyu Widodo, and Firmansyah Firmansyah, (2017), Macroeconomic Stability in Indonesia: Fiscal and Monetary Policies' Framework, International Journal of Economic Perspectives, Volume 11, Issue 4, 341-350. 